\title{
Albeni Falls Wildlife Mitigation Project Idaho Department of Fish and Game 2007 Annual Report
}

\author{
Project No. 1992-061-00 \\ Contract Numbers: \\ IDFG- 00031272; $00031600 ; 00033706$ \\ Prepared for \\ Bonneville Power Administration
}

Final

December 30, 2008

Idaho Department of Fish and Game

Region 1

2885 West Kathleen Street

Coeur d'Alene, Idaho 


\section{Table of Contents}

EXECUTIVE SUMMARY ............................................................................................................. 4

BACKGROUND .................................................................................................................................... 4

WILDLIFE MITIGATION IMPLEMENTATION ............................................................. 6

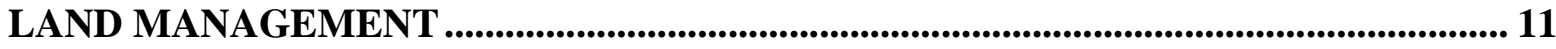

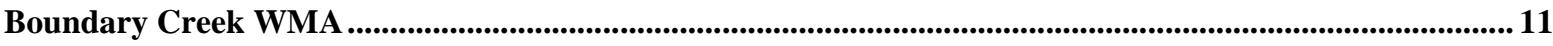

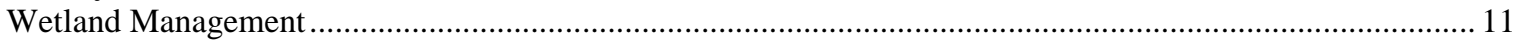

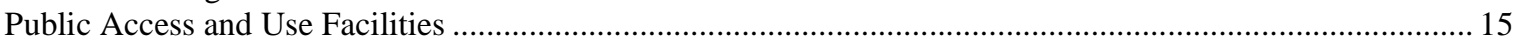

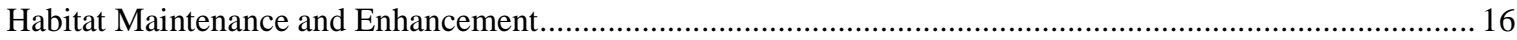

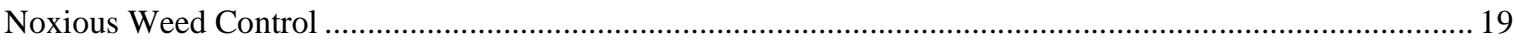

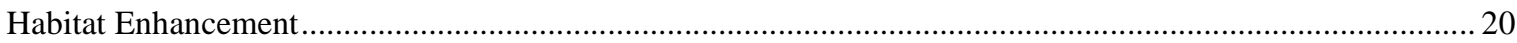

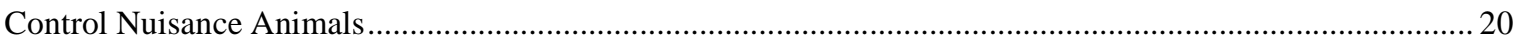

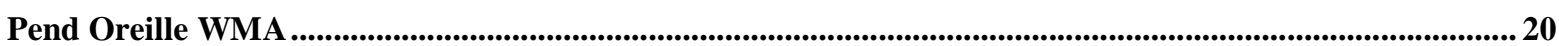

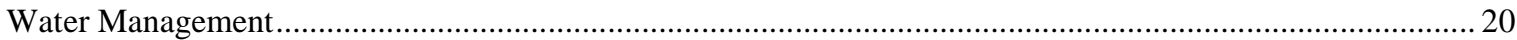

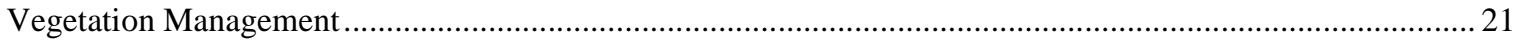

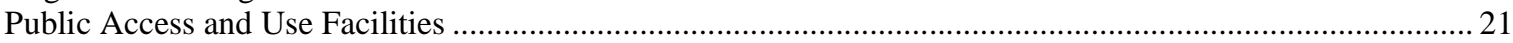

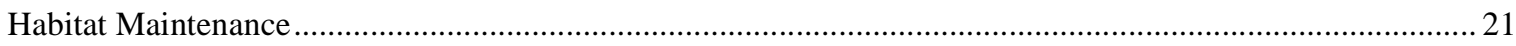

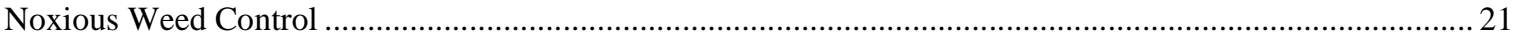

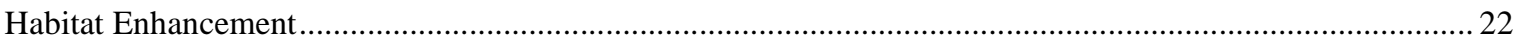

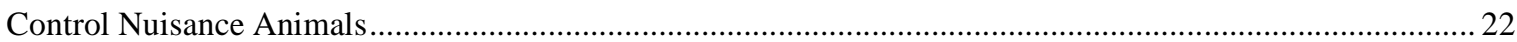

MONITORING AND EVALUATION ..................................................................................... 22

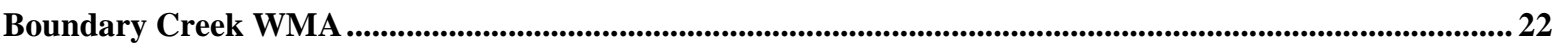

Pend Oreille Combined Lands WMA

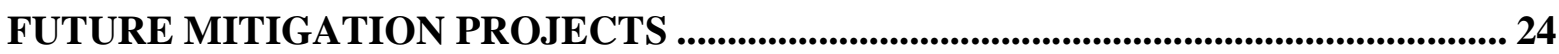

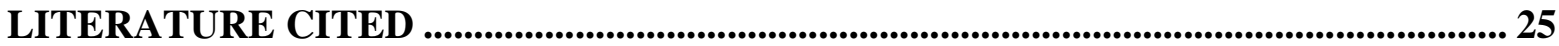

\section{List of Tables}

Table 1. History of wildlife mitigation acquisitions under the Albeni Falls Dam Project ......... 5

Table 2. Total acquisitions completed by the Idaho Department of Fish and Game, acres and

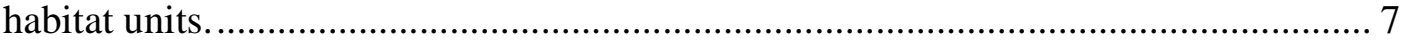

Table 3. Surface area determined by water elevation. ..................................................... 15 


\section{List of Figures}

Figure 1. Map showing the IDFG wildlife management areas, subbasins, and Idaho counties in the Albeni Falls Wildlife Mitigation Project area.................................................... 8

Figure 2. Locations of all Pend Oreille WMA Properties. ...................................................... 10

Figure 3. Boundary Creek Wildlife Management Area wetland complex. ............................. 12

Figure 4. The 1,400-acre Boundary Creek WMA …............................................................... 13

Figure 5. Before and after photos of moist soil management on Wetland Cell 2.................... 14

Figure 6. Biological Technicians using a power auger to plant trees and shrubs..................... 17

Figure 7. Protective fencing for new plantings.

\section{List of Appendices}

Appendix A: Maps showing Albeni Falls Wildlife Mitigation Project properties

Appendix B: Lower St. Joe Habitat Segment of the Coeur d'Alene Wildlife Management Area 2007 Habitat Evaluation Procedure Report

Appendix C: Rapid Lightning Creek Habitat Segment of the Pend Oreille Wildlife Management Area 2007 Habitat Evaluation Procedure Report

Appendix D: Trout Creek Habitat Segment of the Pend Oreille Wildlife Management Area 2007 Habitat Evaluation Procedure Report

Appendix E: Lower Pack River Habitat Segment of the Pend Oreille Wildlife Management Area 2007 Habitat Evaluation Procedure Report

Appendix F: 2007 Vegetation Monitoring and Evaluation Study Boundary Creek Wildlife Management Area, Albeni Falls Wildlife Mitigation Project

Appendix G: 2007 Vegetation Monitoring and Evaluation Study Pend Oreille Wildlife Management Areas, Albeni Falls Wildlife Mitigation Project 


\section{Executive Summary}

The Idaho Department of Fish and Game maintained a total of about 2,743 acres of wildlife mitigation habitat in 2007, and protected another 921 acres. The total wildlife habitat mitigation debt has been reduced by approximately two percent $(598.22 \mathrm{HU})$ through the Department's mitigation activities in 2007. Implementation of the vegetative monitoring and evaluation program continued across protected lands. For the next funding cycle, the IDFG is considering a package of restoration projects and habitat improvements, conservation easements, and land acquisitions in the project area.

\section{Background}

The Pacific Northwest Electric Power Planning and Conservation Act of 1980 (Public Law 96501) directed that measures be implemented by Bonneville Power Administration (BPA) to protect, mitigate and enhance fish and wildlife to the extent affected by development and operation of hydropower projects on the Columbia River system. The Act created the Northwest Power Planning Council (Council), which in turn developed the Columbia River Basin Fish and Wildlife Program (Program). Under the Act, BPA has the authority and obligation to fund fish and wildlife mitigation activities that are consistent with the Council's Program.

The Idaho Department of Fish and Game (IDFG) formed a diverse working group of biologists in 1985, for the purpose of determining wildlife impacts associated with the construction of the Albeni Falls hydroelectric project. Six members from the original working group formally adopted a set of Operating Guidelines in 1998, and established a local decision-making process to address mitigation implementation issues. These active work group members included the IDFG, the Kalispel Tribe (KT), the Kootenai Tribe of Idaho (KTOI), the Coeur d'Alene Tribe (CDAT), the U.S. Fish and Wildlife Service (USFWS), and the U.S. Army Corps of Engineers (USACE). Initially, other non-profit organizations such as the Inland Northwest Land Trust, Ducks Unlimited (DU), and The Nature Conservancy (TNC) have attended meetings and share information, but they are not voting members. Over the past ten years, the working group remained active, and evolved with the changes that occurred in the Program. However, during the past two project solicitation periods (each a three year funding cycle), only four members, the IDFG, KT, CDAT and the KTOI, received funding under the Program and regularly participated in work group meetings.

After recognizing the need for mitigation in 1985, wildlife mitigation implementation activities associated with Albeni Falls Dam began in earnest almost a decade later (Table 1). Most wildlife mitigation projects in the Program involved land acquisition. Initially, BPA funding was primarily directed toward projects proposed by the KT and the IDFG. The KT was first to acquire property under the Program in 1992, and then the IDFG five years later in 1997. Both the KTOI and the CDAT acquired their first wildlife mitigation projects in 2002. Since 2002, however, the KTOI work group member has been unable to bring wildlife a mitigation project forward, and currently the KTOI have two wildlife mitigation parcels totaling 210 acres, and yielding 185.4 HU, a noticeable inequity amongst the four participating members. 
Table 1. History of wildlife mitigation acquisitions under the Albeni Falls Dam Project, acres and habitat units (HU). KT = Kalispel Tribe; IDFG = Idaho Department of Fish and Game; CDAT = Coeur d'Alene Tribe; KTOI = Kootenai Tribe of Idaho (source: AFIWG 2007).

\begin{tabular}{|c|c|c|c|c|c|}
\hline Name & Location & Year & Member & Acres & HU \\
\hline Goose Haven Lake & St. Maries & 2002 & CDAT & 647.7 & 266.9 \\
\hline Windy Bay & Lake Creek & 2002 & CDAT & 147.6 & 66.9 \\
\hline Hanson & Hangman Creek & 2005 & CDAT & 910 & 192 \\
\hline Felsmen & Hangman Creek & 2005 & CDAT & 157 & 54 \\
\hline Kitt & Hangman Creek & 2005 & CDAT & 315 & 118 \\
\hline \multirow[t]{2}{*}{ Cougar } & Coeur d'Alene River & 2006 & CDAT & 163.1 & 128 \\
\hline & & & Totals & $2,340.4$ & 825.8 \\
\hline Derr Creek & Clark Fork & 1997 & IDFG & 240 & 373.3 \\
\hline Carter's Island & Clark Fork Delta & 1997 & IDFG & 95.9 & 311.8 \\
\hline Denton Slough & Hope & 1997 & IDFG & 16.8 & 41.4 \\
\hline Rapid Lightning & Lower Pack River & 1998 & IDFG & 110 & 203.7 \\
\hline Boundary Creek & Boundary Creek & 1999 & IDFG & $1,405.0$ & 606.9 \\
\hline Trout Creek & Lower Pack River & 1999 & IDFG & 216 & 426.8 \\
\hline Lower Pack River & Lower Pack River & 1999 & IDFG & 30 & 84.3 \\
\hline Cocolalla Lake & Cocolalla Lake & 1999 & IDFG & 98 & 143.6 \\
\hline Albeni Cove & Albeni Cove & 1999 & IDFG & 70 & 95.1 \\
\hline Westmond Lake & Westmond Lake & 1999 & IDFG & 65 & 86.7 \\
\hline Deep Creek & McArthur Wildlife Corridor & 2005 & IDFG & 40 & 77.5 \\
\hline Gold Creek & Pack River & 2005 & IDFG & 310 & 606.2 \\
\hline Shields & Pack River & 2006 & IDFG & 41 & 41 \\
\hline Conner Lot & Pack River & 2006 & IDFG & 0.24 & 1 \\
\hline & & & Totals & $2,737.9$ & $3,099.3$ \\
\hline Flying Goose I & Usk & 1992 & KT & 436 & 945 \\
\hline Flying Goose II & Usk & 1997 & KT & 164 & 367.5 \\
\hline Nacarotto & Priest River & 2000 & KT & 63 & 105.4 \\
\hline Sivert & Cusick & 2000 & KT & 437 & 358.3 \\
\hline Doramus & Cusick & 2000 & $\mathrm{KT}$ & 303 & 183.2 \\
\hline Scheibel & Cusick & 2001 & $\mathrm{KT}$ & 440 & 528 \\
\hline Carey Creek & Priest River & 2002 & $\mathrm{KT}$ & 117 & 164.1 \\
\hline Beaver Lake & Bottle Bay & 2002 & $\mathrm{KT}$ & 255 & 216 \\
\hline Gamlin Lake & Bottle Bay & 2002 & $\mathrm{KT}$ & 156 & 244.6 \\
\hline Upper Trimble North & Cusick & 2004 & $\mathrm{KT}$ & 241 & 120 \\
\hline Tacoma South & Cusick & 2004 & KT & 94 & 190.8 \\
\hline Calispell Creek & Cusick & 2004 & $\mathrm{KT}$ & 160 & 138.2 \\
\hline Beaver Lake (Hellar) & Bottle Bay & 2004 & $\mathrm{KT}$ & 90 & 235.1 \\
\hline Beaver Lake (Korengutt) & Bottle Bay & 2004 & KT & 40 & 103.1 \\
\hline Beaver Lake/Eaton Lake & Bottle Bay & 2005 & $\mathrm{KT}$ & 80 & 201.13 \\
\hline Carney-Calispell Creek & Cusick & 2006 & KT & 418 & 185 \\
\hline & & & Totals & $3,494.0$ & $4,285.4$ \\
\hline Perkins Lake & Moyie Springs & 2002 & KTOI & 98.6 & 115.4 \\
\hline Trout Creek Peninsula & Kootenai River Flood Plain & 2002 & KTOI & 112 & 70 \\
\hline & & & Totals & 210.6 & 185.4 \\
\hline
\end{tabular}


Interestingly, no projects were completed under the Program in 2003, and some members went years without completing projects (Table 1). By 2004, however, high property values, as well as the desire for people to move and live in the Pend Oreille basin and surrounding project area ${ }^{1}$, created a competitive market for in-basin/in-kind habitat. Also during this period, the Columbia Basin Fish and Wildlife Authority's (CBFWA) Wildlife Advisory Committee suffered with funding, participation and crediting issues. In May 2005, the KT chose to discontinue their participation in the CBFWA, citing a lack in confidence in the organization's staff or membership in relationship to the tribe's sovereignty and needs. Still, even within the atmosphere of crediting and political difficulties seen in the CBFWA, by the end of 2006, a total of 38 wildlife mitigation acquisitions were completed under the Albeni Falls Wildlife Mitigation Project, totaling $8,782.9$ acres and yielding 8,395.9 habitat units.

During 2007, the four members of the Albeni Falls Interagency Work Group met to discuss possible strategies to allocate remaining habitat units. Some of the discussions revolved around the work group members considering strategies to settle the mitigation debt to BPA. Through these discussions it became apparent that the four entities had different mitigation strategies for the Albeni Falls Wildlife Mitigation Project. Many of these differences were driven by their respective entity objectives and missions.

Therefore, the four work group members are considering new mitigation approaches for the next BPA solicitation process given the 1) limitations in spending capital funding and Program timeline constraints, 2) high property value and competitive real estate markets in the project area, 3) plus the differences in work group member missions and objectives.

\section{Wildlife Mitigation Implementation}

In 2007, IDFG completed five land acquisition projects under the Albeni Falls Wildlife Mitigation Project adding 620 acres to the Boundary Creek WMA, 239 acres to the Pend Oreille WMA, and 62 acres to the St. Joe River (Table 2) in the Coeur d'Alene basin (Figure 1).

\section{Smith Creek, Kootenai Subbasin}

The first project involved a donation of the 620-acre Smith Creek property in Boundary County to IDFG by Ducks Unlimited. This project was brought forward to the IDFG by the KTOI work group member in November 2005, and then approved by the Albeni Falls Interagency Work Group on the contingency that BPA receives no more than ten percent of the current crediting or future habitat units for the property. Ducks Unlimited transferred the fee-title ownership to IDFG in early 2007. A Habitat Evaluation Procedures (HEP) survey was completed in 2006, finding that the property provided 855.3 habitat units (HU) yielding 1.33 habitat units per acre. A total of $86 \mathrm{HU}$ were credited to BPA for operation and maintenance of the property.

\footnotetext{
${ }^{1}$ Project Area is defined in the 1996 EA - general area around Pend Oreille Lake and River in Northern Idaho. Upon completion of the EIS on March 24, 1997, the project area was expanded to include all of Benewah, Shoshone, Kootenai, Bonner, and Boundary Counties in Northern Idaho.
} 
Table 2. Total acquisitions completed by the Idaho Department of Fish and Game, acres and habitat units (HU). HEP = Habitat Evaluation Procedures.

\begin{tabular}{|c|c|c|c|c|c|}
\hline Project & Year Acquired & Acres & HEP & HU & Comments \\
\hline \multicolumn{6}{|c|}{ Boundary Creek and Northern Wildlife Management Areas } \\
\hline Boundary Creek & June 1, 1999 & 1,405 & $\begin{array}{l}\text { HEP 5-year } \\
\text { June 5-9,2006 }\end{array}$ & 606.96 & $\begin{array}{l}\text { BPA contributed } 29.8 \% \text { of } \\
\text { total purchase price }\end{array}$ \\
\hline Deep Creek & July 19, 2005 & 40 & $\begin{array}{l}\text { May 29, } 2006 \\
\text { (Baseline) }\end{array}$ & 77.53 & \\
\hline Smith Creek O\&M & January 7, 2007 & 620 & $\begin{array}{l}\text { September } 2006 \\
\text { (Baseline) }\end{array}$ & 86 & $\begin{array}{l}\text { Donated by DU; } 10 \% \text { of total } \\
\text { HU allocated }\end{array}$ \\
\hline Total & & 2,065 & & 770.49 & \\
\hline \multicolumn{6}{|c|}{ Pend Oreille Wildlife Management Area } \\
\hline Albeni Cove & $\begin{array}{l}\text { September 16, } 1999 \\
\text { September 23, } 1999\end{array}$ & 70 & $\begin{array}{l}\text { HEP 5-year } \\
\text { May 15-17, } 2006\end{array}$ & 95.1 & \\
\hline Carter's Island & August 28, 1997 & 96 & $\begin{array}{l}\text { November 6, } 1998 \\
\text { (Baseline) }\end{array}$ & 311.82 & $\begin{array}{l}\text { Using baseline HEP as the 5- } \\
\text { year HEP results were } \\
\text { questionable. Conducting a } \\
\text { new HEP survey in } 2008 \text {. }\end{array}$ \\
\hline Cocolalla Lake & November 1, 1999 & 98 & $\begin{array}{l}\text { HEP 5-year } \\
\text { June 21-23, } 2006\end{array}$ & 186.13 & \\
\hline Denton Slough & December 11, 1997 & 17 & $\begin{array}{l}\text { November 6, } 1998 \\
\text { (Baseline) }\end{array}$ & 41.44 & $\begin{array}{l}\text { Using baseline HEP as the } 5 \text { - } \\
\text { year HEP results were } \\
\text { questionable. Conducting a } \\
\text { new HEP survey in } 2008 \text {. }\end{array}$ \\
\hline Derr Creek & July 7, 1997 & 240 & $\begin{array}{l}\text { HEP 5-year } \\
\text { September 11, } 2003\end{array}$ & 379.33 & \\
\hline Gold Creek & November 29, 2005 & 310 & $\begin{array}{l}\text { May 22, } 2006 \\
\text { (Baseline) }\end{array}$ & 606.22 & \\
\hline Lower Pack River & September 18, 1999 & 30 & & & \\
\hline $\begin{array}{r}\text { Conner Lot } \\
\text { Liu Lot }\end{array}$ & $\begin{array}{l}\text { July 26, } 2006 \\
\text { March 9, } 2007\end{array}$ & $\begin{array}{l}0.26 \\
0.55\end{array}$ & $\begin{array}{l}\text { HEP 5-year } \\
\text { June } 2008\end{array}$ & 83.87 & $\begin{array}{l}\text { HEP conducted in } 2006 \text {, and } \\
\text { report updated due to new } \\
\text { acquisitions. }\end{array}$ \\
\hline Wilson Lot & December 5, 2007 & 0.74 & & & \\
\hline $\begin{array}{l}\text { Rapid Lightning } \\
\text { Pack River Ridge } \\
\text { Ginter }\end{array}$ & $\begin{array}{l}\text { January 20, } 1999 \\
\text { July 27, } 2006 \\
\text { April/October } 2007\end{array}$ & $\begin{array}{r}110 \\
41 \\
210.49\end{array}$ & $\begin{array}{l}\text { HEP 10-year } \\
\text { May } 2007\end{array}$ & 603.62 & $\begin{array}{l}\text { HEP surveys conducted in } \\
2007 \text {, to update project with } \\
\text { new acquisitions. }\end{array}$ \\
\hline $\begin{array}{l}\text { Trout Creek } \\
\qquad \begin{array}{r}\text { Avista cost-share } \\
\text { Stevens }\end{array}\end{array}$ & $\begin{array}{l}\text { October 7, } 1999 \\
\text { December 11, } 2007 \\
\text { February 13, } 2008\end{array}$ & $\begin{array}{r}216 \\
27.3 \\
5\end{array}$ & $\begin{array}{l}\text { HEP 5-year } \\
\text { May } 2007\end{array}$ & 446.33 & $\begin{array}{l}\text { HEP surveys conducted in } \\
2007 \text {, to update project with } \\
\text { new acquisitions (Stevens Lot } \\
\text { included). }\end{array}$ \\
\hline Westmond Lake & November 1, 1999 & 65 & $\begin{array}{l}\text { HEP 5-year } \\
\text { June 19-20, } 2006\end{array}$ & 86.72 & \\
\hline & Totals & $\mathbf{1 , 5 3 7}$ & & $2,840.58$ & \\
\hline \multicolumn{6}{|l|}{ Coeur d'Alene WMA } \\
\hline \multirow[t]{2}{*}{ Lower St. Joe River } & March 9, 2007 & 62 & $\begin{array}{l}\text { May 10-11, } 2007 \\
\text { (Baseline) }\end{array}$ & 86.45 & \\
\hline & Overall Totals & 3,664 & & $3,697.52$ & \\
\hline
\end{tabular}




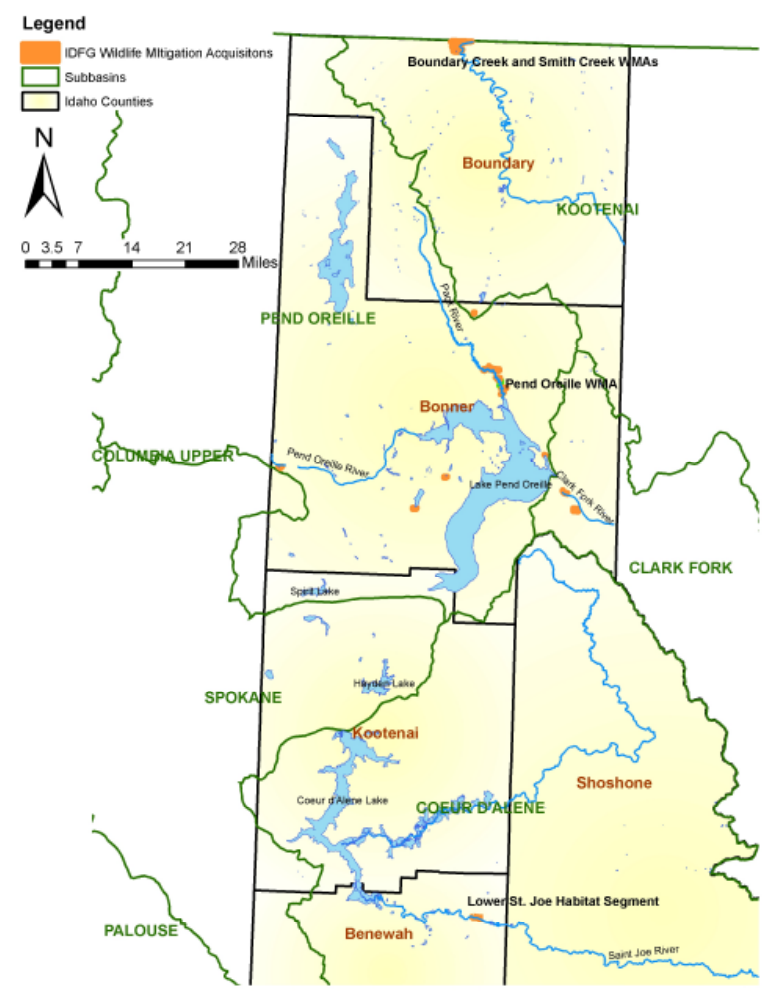

Figure 1. Map showing the IDFG wildlife management areas, subbasins, and Idaho counties in the Albeni Falls Wildlife Mitigation Project area.

Lower St. Joe, Coeur d'Alene Subbasin

The second project identified by IDFG in 2006, and completed in early 2007, involved the acquisition of 62 acres of St. Joe River floodplain in Benewah County for $\$ 620,000$. The primary wildlife values associated with this parcel involve the restoration of the St. Joe River floodplain habitat. Most of the broad floodplain areas in northern Idaho were converted to agricultural fields in the early 1900s. These same agricultural areas are currently being converted to waterfront home sites and small, platted summer recreational vehicle campsites, further reducing wildlife habitat values. The 62-acre floodplain area can be restored to wetland conditions by plugging a series of drains and by plantings of woody vegetation. An excellent opportunity also exists to expand the floodplain restoration activities by partnering with Avista Corporation. Avista currently owns an adjoining, upstream parcel of similar size. The company recently relicensed their Spokane River hydropower facilities, including Post Fall Dam which backs Lake Coeur d'Alene into this reach of the St. Joe River. Significant wetland mitigation actions were associated with the current FERC license application and it is anticipated upon securing a FERC license that Avista will work with IDFG to use their adjoining parcel to fulfill a portion of the wetland mitigation obligation. A baseline HEP for this 62-acre parcel was completed in the spring of 2007 (Appendix B), and a management plan is pending. In total, the Lower St. Joe parcel provides 86.45 habitat units (HU) on 65.9 acres (1.31 habitat units per acre).

Rapid Lightning Creek, Pend Oreille Subbasin

The remaining wildlife mitigation projects occurred in the Pend Oreille basin, and included three acquisitions along the Pack River in Bonner County. The first project was 
a 238-acre acquisition initiated early 2006, when the Ginter family contacted the IDFG expressing their desire to sell the remainder of their property along the Pack River. The Ginter family had conveyed the Rapid Lightning Habitat Segment (110 acres) to the Department via the BPA wildlife mitigation program in 1999. The family now wanted to keep their home site area, and convey their remaining property to the wildlife mitigation project in two parcels, the northern parcel consisting of about 210 acres and the southern parcel consisting of 27.3 acres. The IDFG also coordinated with the Avista Corporation to cost-share the acquisition of the southern most 27.3-acre parcel. This parcel borders the Trout Creek Habitat Segment and provides continuity between Trout Creek Habitat Segment and the Shields property acquired in 2006 (Table 2).

In early 2007, the Albeni Falls work group members agreed to rank the project and the project was completed in two stages, totaling $\$ 1,920,870$. After the completion of the Ginter acquisition, the IDFG combined the current Rapid Lightning Habitat Segment along with the newly acquired Shields and Ginter parcels to create a single habitat segment (HS) called Rapid Lightning Creek (Figure 2). The 27.3 acre parcel was combined with the Trout Creek Habitat Segment (see Appendix A for maps of individual properties). Baseline HEP surveys were completed for the new habitat segments in the spring of 2007 (Appendices C and D). In total, the Rapid Lightning Creek HS provides 603.62 habitat units (HU) on 361.47 acres (1.67 habitat units per acre).

\section{Lower Pack River, Pend Oreille Subbasin}

Two lots were also acquired and added to the Lower Pack River Habitat Segment (Figure 2) on March 9, 2007 (0.55 acres for \$40, 000), and December 5, 2007 (0.74 acres for $\$ 45,000)$. Acquisition of these two lots now allow the IDFG to work with the county planning and zoning office to abandon the subdivision plats on the property, and reposition a platted right-of-way off a wetland area. The newly acquired parcels were classified by habitat type and combined with the acreages of habitat types in the existing property. Because the habitats of the new parcels are so similar to the habitats of the existing property, a new field survey was not required and an updated HEP was completed in 2008 (Appendix E). Overall, the Lower Pack River HS provides 83.87 habitat units (HU) for the targeted species on 30.75 acres (2.73 habitat units per acre).

The IDFG is also in the process of reorganizing and preparing new management plans for the Albeni Falls wildlife mitigation properties. First, the Pend Oreille WMA Plan was restructured to facilitate the addition or combining of wildlife mitigation habitat segments. The management plan was prepared with a framework and then a series of appendixes for each management parcel and the three year budget under the plan. This new format will allow the IDFG to add or combine parcels without impacting the entire plan. This design will also allow the plan to follow the budgeting cycles under the Council's Program.

Similarly, the 40-acre Deep Creek Habitat Segment located near the McArthur Lake WMA, the Boundary Creek WMA, and the newly acquired Smith Creek parcel will be combined into a single management plan for the northern wildlife mitigation parcels. For the time being, the newly acquired Lower St. Joe habitat segment will be managed under the Coeur d'Alene WMA, but funded under the Pend Oreille WMA expense contract. 


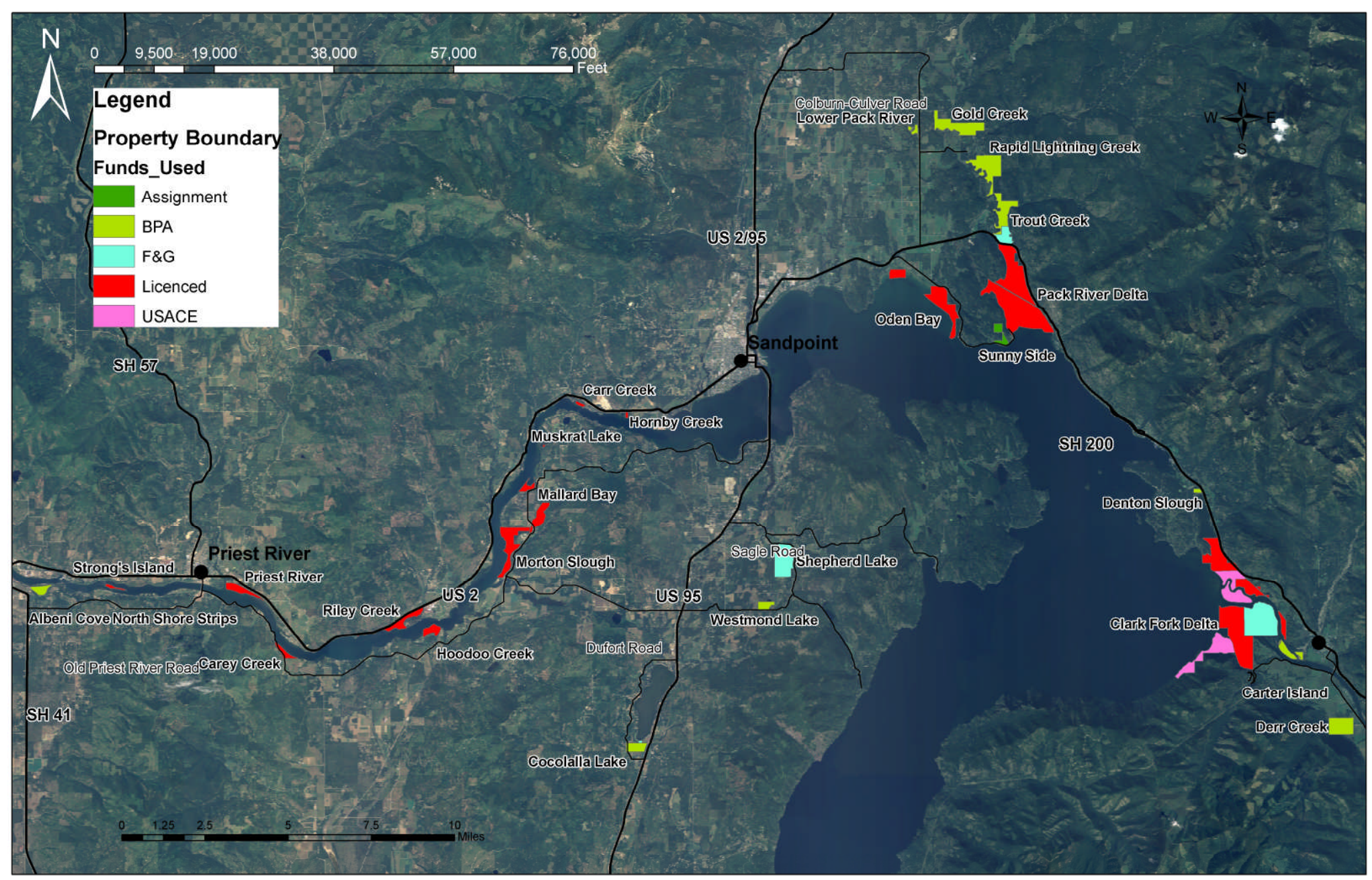

Figure 2. Locations of all Pend Oreille WMA Properties. . Individual parcels are shown in Appendix A. Ten properties totaling 1,513 acres (shown in bright green) are designated as wildlife mitigation properties under the Albeni Falls Wildlife Mitigation Project (photograph taken in 2004). 


\section{Land Management}

\section{Boundary Creek WMA}

\section{Wetland Management}

Water levels on the Boundary Creek Wildlife Management Area (BCWMA) are managed to mimic natural floodplain hydrology. Generally, this means high spring water levels that peak in June, receding summer water levels, and naturally recovering fall/winter water levels. The WMA is composed of a total of eight basin wetland cells (Figures 3 and 4). Advantages to this hydrology include facilitated nutrient cycling, establishment of diverse emergent plant assemblages, and productive habitat for waterfowl, shorebirds, and other wildlife.

During late-fall and winter, run-off due to periodic precipitation is naturally stored in wetland basins. From mid-March to mid-June, water from Boundary Creek is used to raise water levels to desired annual maximums. Habitat Managers attempt to reach maximum water elevations by early April to prevent flooding duck nests established in shoreline vegetation; however, to mimic natural floodplain hydrology, peak water level elevations should be reached by early June (the time of natural peak flooding). Water levels typically begin to recede after this time and concentrate food items at the soil/water interface for duck broods and shorebirds. This recession also facilitates development of diverse assemblages of emergent plant species, which increase habitat complexity. By October, fall precipitation may slow the rate of decline and increase water levels.

Water levels across the BCWMA wetland complex have been recorded monthly since March 2001, by measuring down from the top of selected water control structures to the water level. Wetland surface area was determined by the measured water elevation (Table 3).

The BCWMA held less water in 2007, than it did in 2006. Water levels in Wetland Cells 2 and 3 were drawn down to manage for moist soil vegetation management. However, Wetland Cells 1, 3, 4, 5 and 8 were drawn down due to an extremely dry summer season.

The vegetative response in Wetland Cell 2 was incredible, with bidens, water grass, and smartweed attaining heights of over 6 feet (Figure 5). The high-volume pump was used to gradually re-flood the cell in late-September. This allowed waterfowl to continually utilize the food source throughout the fall. Full pool was reached by early-December and held there over winter to benefit muskrats.

Bidens, water grass, and smartweed were all observed along the periphery of Wetland Cell 3, but the growth was not as extensive as that observed in Wetland Cell 2. This was because the water table was substantially lower in Wetland Cell 3. Additionally, cottonwoods germinated along the periphery of the cell and on the exposed mud flats. 


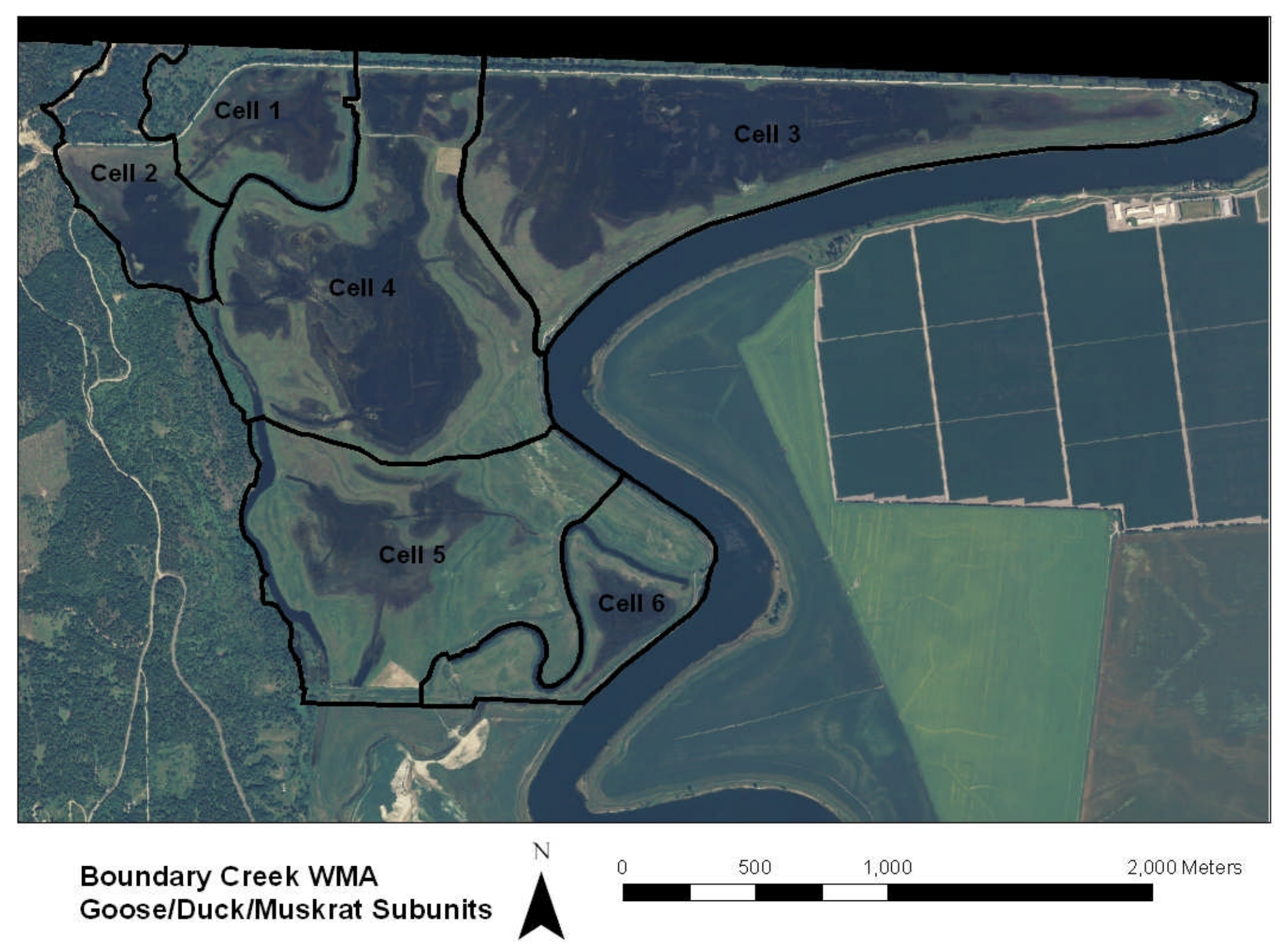

Figure 3. Boundary Creek Wildlife Management Area wetland complex. 


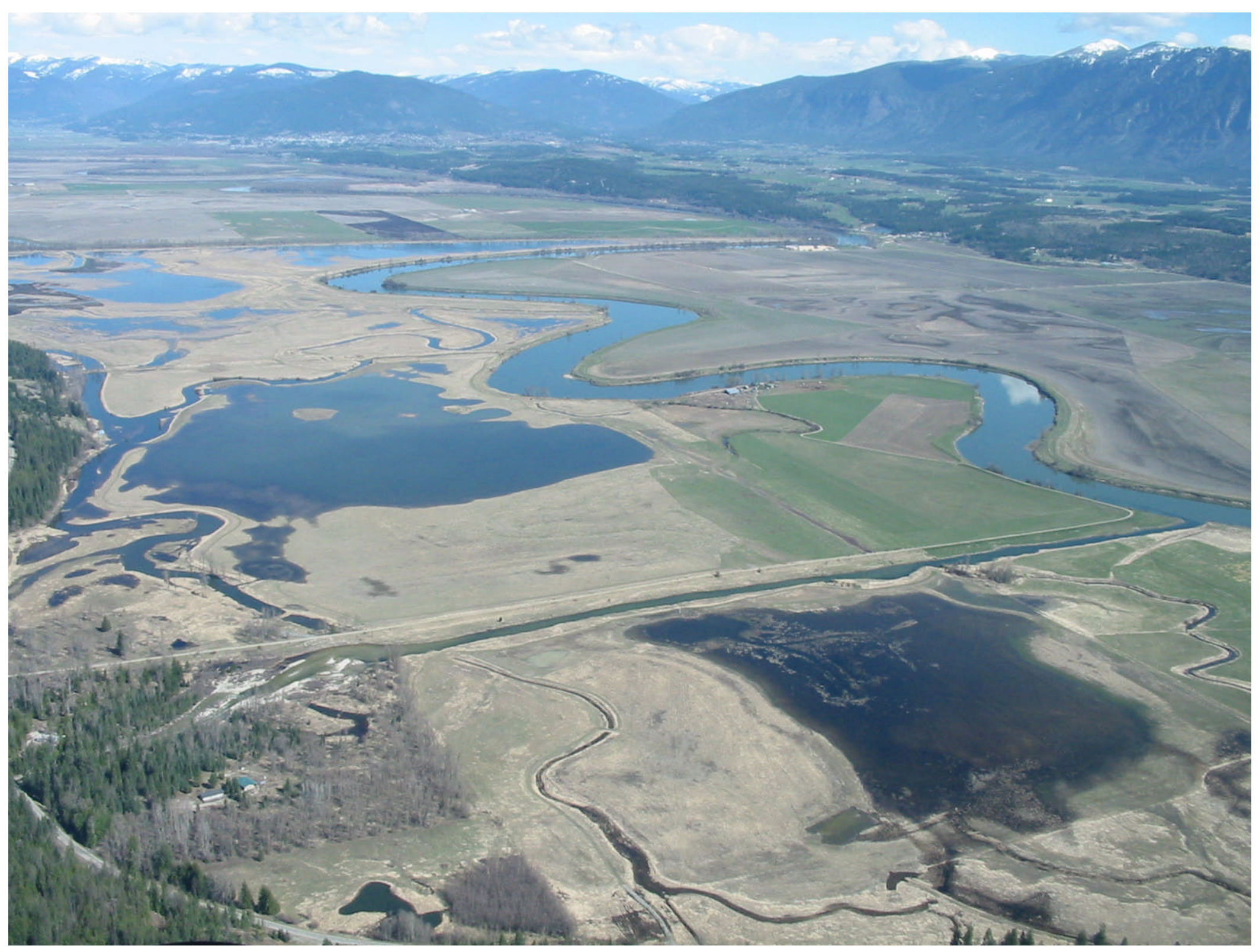

Figure 4. The 1,400-acre Boundary Creek WMA, April 2007 (looking north). A portion of the 640-acre Smith Creek WMA is shown in to the south. 


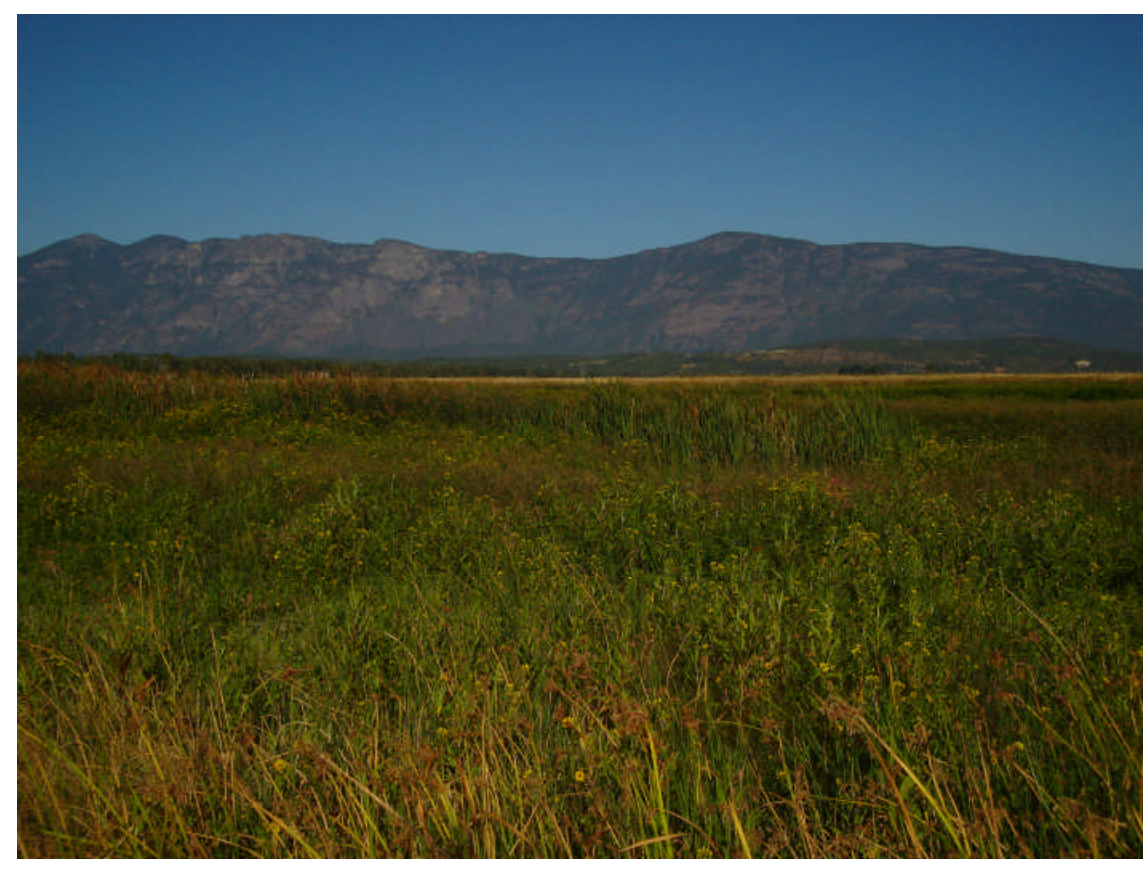

May

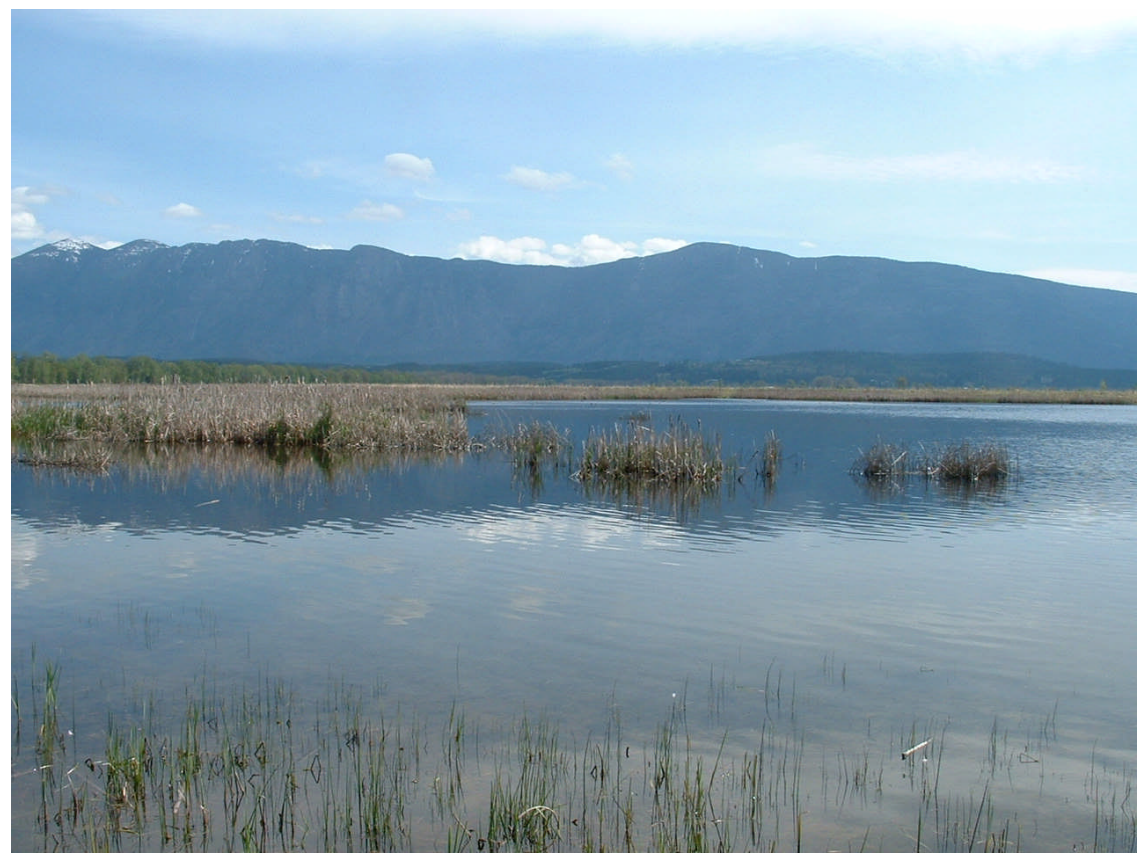

August

Figure 5. Before and after photos of moist soil management on Wetland Cell 2. 
Table 3. Surface area determined by water elevation.

\begin{tabular}{|c|r|r|r|r|r|r|}
\hline & \multicolumn{7}{|l|}{$\begin{array}{l}\text { Wetland surface area (acres) by water level elevation } \\
\text { (excluding slough channel surface areas) }\end{array}$} \\
\hline $\begin{array}{c}\text { Water } \\
\text { Elevation }\end{array}$ & Cell 1 & \multicolumn{1}{c|}{ Cell 2 } & \multicolumn{1}{c|}{ Cell 3 } & \multicolumn{1}{c|}{ Cell 4 } & \multicolumn{1}{c|}{ Cell 5 } & \multicolumn{1}{c|}{ Cell 6 } \\
\hline $1,749.0$ & 0 & 0 & 25.4 & 0 & 0 & 0 \\
\hline $1,749.5$ & 0 & 0 & 43.7 & 0 & 0 & 0 \\
\hline $1,750.0$ & 0 & 0 & 62.0 & 2.2 & 0 & 0.4 \\
\hline $1,750.5$ & 0 & 0 & 75.5 & 3.6 & 0 & 2.8 \\
\hline $1,751.0$ & 0 & 0 & 89.0 & 5.0 & 0 & 5.2 \\
\hline $1,751.5$ & 3.2 & 2.0 & 107.9 & 32 & 2.1 & 6.8 \\
\hline $1,752.0$ & 6.4 & 4.9 & 126.7 & 59.0 & 4.1 & 8.4 \\
\hline $1,752.5$ & 9.3 & 13.1 & 139.5 & 76.4 & 11.6 & 10.0 \\
\hline $1,753.0$ & 12.1 & 16.3 & 152.3 & 93.8 & 19.0 & 11.5 \\
\hline $1,753.5$ & 16.4 & 19.5 & 167.2 & 114.4 & 28.3 & 13.4 \\
\hline $1,754.0$ & 20.6 & 22.7 & 182.0 & 135.0 & 37.6 & 15.3 \\
\hline $1,754.5$ & 28.3 & 25.7 & 197.3 & 153.0 & 48.5 & 16.8 \\
\hline $1,755.0$ & 35.9 & 28.6 & 212.6 & 171.0 & 59.3 & 18.3 \\
\hline
\end{tabular}

Unfortunately, Habitat Managers were unable to re-fill the remaining cells because of their high volume. Wetland Cells 3-5 and 8 remained at capacities from 0\%-30\% of full pool over the winter. Water levels in Wetland Cells 6 and 7 were reduced in 2007, but were not affected as severely as the other cells over the summer. They maintained capacities of $55 \%$ and $85 \%$, respectively, over the winter.

However, one unexpected benefit of the reduced water levels was the shorebird use. The vast exposed mud flats provided extensive foraging habitat for migrating shorebirds. The BCWMA became a favored destination for local birders in fall 2007 (12 shorebird species were observed on September 1, 2007).

\section{Public Access and Use Facilities}

Public use facilities developed in 2003, were regularly maintained in 2007. Existing gates and fences were maintained and walking/biking trails were regularly mowed to facilitate non-motorized public use of the BCWMA.

The access site on the main slough was again cleared of course woody debris to make it more accessible to the public. The debris was distributed throughout the BCWMA to continue to provide habitat. This project has become an annual activity and will continue to be until the majority of the debris has been removed. 


\section{Habitat Maintenance and Enhancement}

\section{Native Tree and Shrub Re-establishment}

An important habitat restoration measure for the BCWMA is re-establishment of native trees and shrubs on the floodplain portion of the area. Native trees and shrubs serve as browse and cover for big game, provide habitat for non-game birds, and eventually will provide habitat for cavity nesting ducks, and other cavity-dependent wildlife. General Land Office notes from 1898, and observation of existing undisturbed portions of the Kootenai Valley indicate native trees and shrubs included (in approximate order of prevalence): black cottonwood; red-osier dogwood; woods rose; western snowberry; chokecherry; willow; aspen; serviceberry; black hawthorn; and, other native shrubs.

Tree and shrub plantings have been completed on the BCWMA since fall of 2001. Plantings included 5-8 feet cottonwood post cuttings and 1-gallon containerized plants of other species. Planting holes were dug using a six-inch posthole auger. Plantings were conducted during dormancy in fall (late October or early November) and spring (early April). Plants were protected from girdling by small mammals using four inch diameter black corrugated drainpipe cut into eight-inch sections and placed around the plant. Further, each plant was protected from ungulate browsing using 48 inch utility wire fencing cut in three foot sections and formed into a 12 inch diameter tube that was placed over the plant and anchored using bamboo sticks. Use of $3 \mathrm{X} 3$ foot weed control mats is not recommended because small mammals used the mats for shelter and girdled nearby plants. Past tree and shrub planting locations included the east side of Wetland Cells 1 and 2 (October 2001), the north and west sides of Wetland Cell 6 (April 2002), the south side of Wetland Cell 4 (November 2002), cottonwood post plantings in other planting sites (April 2003), and the north side of Wetland Cell 5 (November 2003).

Tree and shrub plantings completed prior to 2004 were marginally successful at the BCWMA. In 2004, all tree and shrub plantings were inspected to determine success rates and all dead post cutting plantings were removed, and those trees and shrubs still alive at each location had the original fencing replaced with a 36 inch (radius) by 72 inch (height) galvanized wire fence tube to prevent ungulate browsing in 2005.

Tree and shrub planting resumed in fall 2005. Plantings sites included the north and west sides of Wetland Cell 4, the depression northwest of Wetland cell 5, and surrounding the seasonal wetland southeast of Cell 5. The majority of the plants were protected with a 36 inch (radius) x 72 inch (height) galvanized wire fence tube to prevent ungulate browsing.

In April and late-October 2006, a new technique was used to plant and protect containerized trees and shrubs on the BCWMA. Personal power augers were used to drill the holes (Figure 6). This technique is more efficient than using a skidster or tractor auger. In addition, the three inch radius auger bit creates a much more appropriatelysized hole for the one gallon containerized plants. Planting locations included the west side of Wetland Cell 8, south of Wetland Cell 7, north of Wetland Cell 5, east of Wetland Cell 4, and along the slough north and west of Wetland Cell 4. 
Figure 6. Biological Technicians using a power auger to plant trees and shrubs.
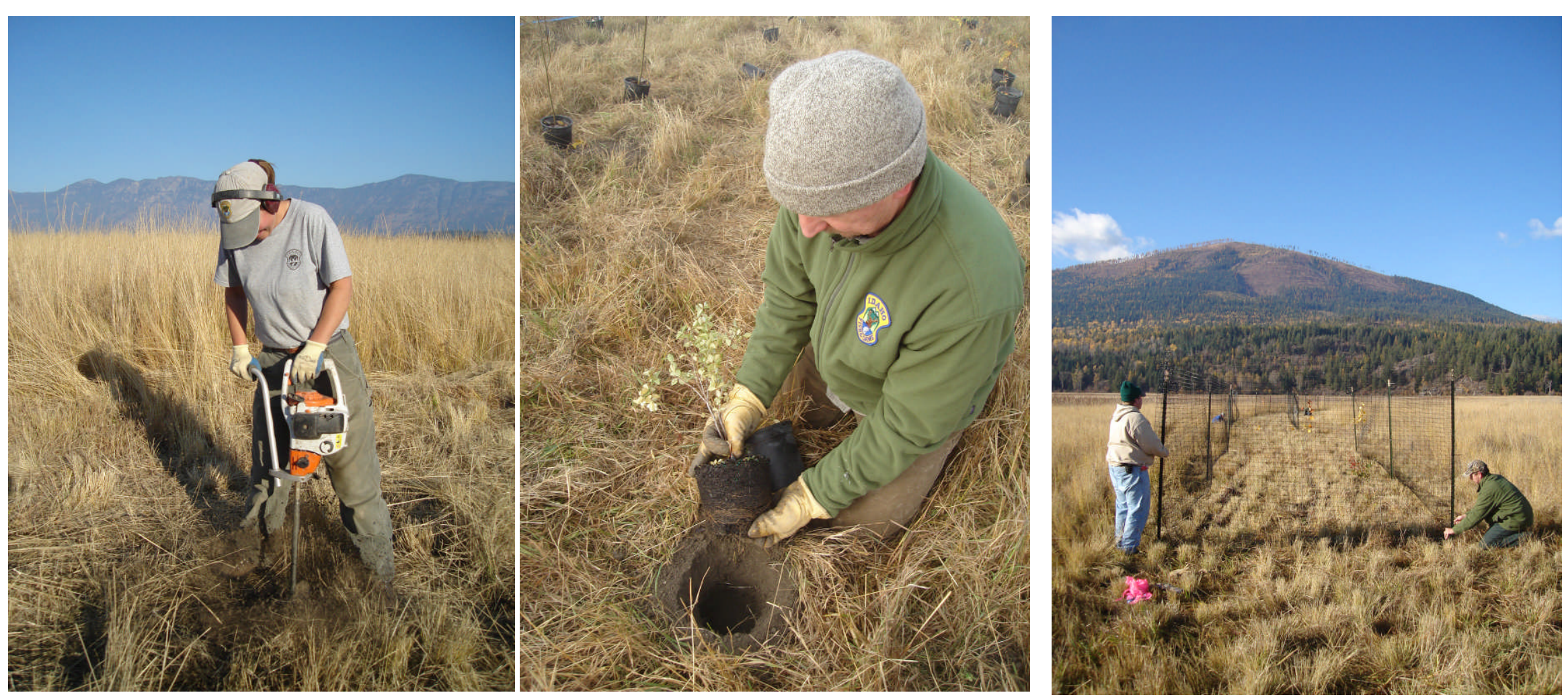

Figure 7. Protective fencing for new plantings. 
Because of the high occurrence of browse on tree and shrub plantings by deer, elk, and moose, all plantings were protected. Trees and shrubs were planted in a 16 inch by 32 inch area and then protected by plastic fencing (Figure 7). The fencing is called 'Deer Defense', is UV-resistant, and is 7.5 feet tall. Six, eight-foot T-posts were used to support the fencing. The fencing was secured to the posts with eight-inch plastic cable ties. The bottoms of the enclosures were secured to the ground with landscape staples. This prevents animals from crawling under the fence.

Unfortunately, many of the spring plantings failed most likely because the plants did not have the ability to soak up spring time runoff and snowmelt. In addition, very dry conditions occurred over the previous two growing seasons that may have contributed to the failures. Finally, many of the spring plantings experienced heavy rodent browsing over the winter months. As a result, the tree and shrub plantings conducted in fall 2007, supplemented the existing tree and shrub enclosures erected in spring 2006.

In addition to supplemental planting, natural tree and shrub establishment is important to the BCWMA. Black cottonwoods are adapted to periodic flooding where high water elevations reduce competing vegetation in inundated areas. They shed their seed about the time floodwaters begin receding, after which they are deposited in drift-lines on exposed mudflats and germinate within hours to days. Provided water levels are not too high in subsequent years, established cottonwood seedlings will survive. In 2003, 2004, and 2007, conditions at the BCWMA were very good for black cottonwood germination. As a result, many black cottonwood and willow saplings were observed emerging from the cattails surrounding the perimeter of many of the wetland cells min 2007. Receding water elevations in late June and July will help to reduce cottonwood seedling mortality associated with extended periods of soil saturation.

\section{Wheat Grass Establishment}

Since spring 2004, prescribed burns have been conducted on the BCWMA grasslands to help further wheat grass establishment. This management activity helps to create a thick stand of wheat grass, and appears to reduce noxious weeds in the burned area. In 2007, eight separate burns were conducted on the BCWMA. These burns were completed in both grassland and wetland areas this past season. Wetland burns were completed in order to slow cattail encroachment on open water habitat. This technique will be utilized in the future to help promote dense nesting cover for waterfowl production on the BCWMA. In no year will the acres burned exceed one third (1/3) of the grasslands on the property.

\section{Wetland Vegetation}

Cursory inspection revealed that emergent wetland plants became established in scattered locations throughout the eight-basin wetland complex. Stands of soft-stem bulrush, cattail, Alisma plantago-aquatica, Ceratophyllum demersum, Elodea canadensis, Eleocharis spp., Chara spp., Potamogeton spp., and Sagittaria spp. were observed. Many other species occurred in scattered small groups across the area. Much of the area has been vegetated since 2004 . 
Cattail control methods were initiated in 2005, and continued in 2006, and 2007. This process entailed a drawdown of Wetland Cell 3. This cell was allowed to dry throughout the summer; cattail patches were mowed with a rotary chopper in August, and allowed to 'green-up'. Afterwards, the sites were sprayed with Habitat ${ }^{2}$, and then gradually re-filled with precipitation. Water levels will be kept high in 2008, in an effort to drown the cattails.

In addition, wild rice (Zizania spp.) was collected from the Coeur d'Alene WMA in September 2004, and seeded at the BCWMA. Small patches of wild rice have been found scattered throughout the cells where seed was dispersed.

In 2004 and 2007, vegetation surveys were conducted at the BCWMA. Two hundred eleven species were documented at 13 of the permanent points. More in depth information can be found in the '2007 Vegetation Monitoring and Evaluation Study: Boundary Creek Wildlife Management Area, Albeni Falls Wildlife Mitigation Project.

\section{Noxious Weed Control}

Perhaps the major management challenge on the BCWMA is control of Canada thistle infestations. Significant staff time and equipment has been directed to the effort. Until 2004, the herbicide selected for use on the BCWMA was 2, 4-D due to short persistence and low cost. However, 2, 4-D can be toxic to invertebrates (e.g., insects), can damage grasses at higher rates of application (i.e., 2+ qt. per acre), and loses effectiveness on Canada thistle as plants mature.

In 2004, Curtail was the dominant herbicide applied to grassland portions of the BCWMA. Transline was substituted in areas where noxious weeds occurred amongst desirable woody vegetation. Due to time constraints and wet spring weather, only approximately half of the BCWMA was treated in 2004.

It became apparent a new noxious weed control plan was necessary. Therefore, the majority of the large grassland areas on the BCWMA were treated by a professional herbicide applicator in 2005. Dan Carlson, Centaurea, Inc. sprayed 514 acres to target primarily Canada thistle, common tansy, hounds tongue, and spotted knapweed. This strategy was used with excellent success on the Pend Oreille WMA and reduced weed control efforts dramatically for the Habitat Manager and technicians responsible for the WMA. The BCWMA technicians treated the remainder of the area (330 acres). A combination of Escort and Hi-Dep was used to treat the majority of the area (because Curtail was not available); however, Transline was again substituted in areas where noxious weeds occurred amongst desirable woody vegetation.

\footnotetext{
${ }^{2}$ Habitat herbicide is an aqueous solution to be mixed with water and a surfactant and applied as a spray solution to control floating and emergent undesirable vegetation. Active ingredient includes Isopropylamine salt of Imazapyr (2-[4,5-dihydro-4-methyl-4-(1-methylenthyl)-5-oxo-1H-imidazol-2-y)-3pyridinecarboxylic acid).
} 
In 2006, the BCWMA technicians treated the grassland areas with Commando. Transline was again substituted in areas where noxious weeds occurred amongst desirable woody vegetation.

Noxious weed control on the BCWMA in 2007, however, was the most extensive and effective effort on record. Approximately 650 acres were assessed for noxious weed infestations in 2007. A total of 632 acres were subsequently treated to control Canada thistle and to a lesser extent absinthe wormwood common tansy, hawkweed, hound's tongue, mullein, oxeye daisy, spotted knapweed, and St. John's wort. The acreage assessed and treated in 2007, has slightly decreased from 2004 from over 1,100 to about 650 acres, because water levels in the wetland areas were much higher this season; therefore, they either did not need to be treated or were inaccessible. In addition, areas that have been treated repeatedly over the past four years have fewer weeds. BCWMA technicians treated the grassland areas with Commando and Milestone. Transline was again substituted in areas where noxious weeds occurred amongst desirable woody vegetation.

\section{Habitat Enhancement}

Four wheat, barley, and sunflower food plots and two food plot strips were established on the BCWMA in 2007. They were planted in late-May, and produced a commercial grade stand of wheat and barley. The sunflowers were sporadic and only a portion of them produced seed heads. The food plots were utilized heavily by pheasants and deer.

Seven brood strips were established in 2007. These strips were comprised of alfalfa, clover, and small burnett, and totaled five acres. Once established these areas will provide herbaceous cover that will produce invertebrates that are critical to pheasant chick survival. These strips will be mowed in 2008 , to reduce noxious weed infestation.

\section{Control Nuisance Animals}

The BCWMA personnel coordinated with USDA-APHIS Wildlife Services to control ravens, coyotes, and skunks, to enhance nesting success and chick survival for a diversity of ground-nesting birds from 2004-2006. However, due to reduced statewide funding for this activity in 2007, no predators were removed from the BCWMA by Wildlife Services in 2007.

\section{Pend Oreille WMA}

\section{Water Management}

All water control structures were inspected and maintained as needed to ensure a safe and functional condition. The old culvert at Rapid Lightning Creek was scheduled for replacement with a new culvert and whistle-stop type water control structure. Work was initiated in fall 2007, but not completed due to adverse weather conditions. Record snow pack and resulting high spring water flows lead to the structural failure of the work in 
progress. The contractor was been notified and repair and completion of this project are scheduled for late summer.

\section{Vegetation Management}

Approximately 20 acres of goose pasture was maintained on different habitat segments through a combination of prescribed burning and mowing. Previous shrub plantings were inspected and maintained.

\section{Public Access and Use Facilities}

All fences, gates, signs, and public parking areas were inspected and maintained as needed to ensure a safe and functional condition. New public parking facilities were constructed at the Gold Creek Habitat Segment. The property boundary was marked with carsonite posts and signs identifying the property. New informational signage will be erected at Gold Creek in the coming field season.

New directional signs to aid the public in crossing private land and accessing the Rapid Lightning Habitat segment were installed. The easement road was rocked to provide a better all-weather surface and to address dust concerns voiced by neighbors.

Unusually high snowfall this year resulted is a partial structural failure of the pole barn storage facility at the Derr Creek Habitat Segment. All damage was repaired. The structural integrity of the building was assessed and the building has been reinforced against failure under similar conditions in the future. There was no damage to building contents.

\section{Habitat Maintenance}

Two miles of fence were installed at Gold Creek and 800 feet were installed at Denton Slough to exclude grazing cattle. These properties are located in open range herd districts and it is the landowner's responsibility to fence cattle off there ownership. All goose platforms and wood duck nesting boxes were serviced.

\section{Noxious Weed Control}

All Wildlife Mitigation parcels purchased under the Albeni Falls Wildlife Mitigation Project were inspected for noxious weeds. Herbicides were applied to approximately 80 acres of the WMA to control noxious weed infestations. All BPA parcels were inspected for noxious weeds. Herbicides were applied to approximately 80 acres of the WMA to control noxious weed infestations.

Although a variety of noxious weeds were treated, the biggest problem in wetland and riparian margins is common tansy. Spotted knapweed was the primary target in upland areas, especially on the recently acquired Gold Creek parcel with it long history of grazing disturbance. Curtail and Transline were the most commonly applied herbicides. 
Parking areas were treated with a combination of Razor-Pro and Surflan to kill all vegetation present and prevent new emergent growth.

\section{Habitat Enhancement}

Additional waterfowl nesting structures were installed at the Gold Creek and Rapid Lightning Habitat Segments. Cattle were excluded from access to the Gold Creek parcel, as well as to the Denton Slough Habitat Segment. Replacement of the culvert at Rapid Lightning with a small whistle stop type of water control structure will improve water management and enhance waterfowl habitat.

\section{Control Nuisance Animals}

No nuisance animal concerns arose on the WMA this year. Animal damage control is coordinated with the U.S. Fish and Wildlife Service.

\section{Monitoring and Evaluation}

\section{Boundary Creek WMA}

IDFG staff conducted vegetation surveys from July 9 to August 22, 2007. Up to 211 different species were encountered on the WMA (Appendix F). Wetland hydrology and wetland basins have been restored to the flood plain. This is apparent in number of samples on the floodplain supporting submergent and emergent wetland vegetation. Of the samples completed on the floodplain, 17 of the 46 samples (37\%) had sufficient inundation to support emergent vegetation communities and five of the 46 samples (11\%) supported submergent vegetation communities. The results show that the restoration of native vegetation communities is progressing slowly on the Kootenai River floodplain. Introduced species dominate the meadow communities, make-up a significant portion of the emergent vegetation (marsh) communities, and play a minor role in the submergent vegetation (open water/mud flat) communities.

New areas of scrub-shrub wetland communities or cottonwood forest communities have not yet been established, although natural seedings of black cottonwood (Populus balsamifera ssp. trichocarpa) and willows (Salix ssp.) are occurring in the wetland basins of Boundary Creek WMA. Furthermore, thousands of native shrubs and wetland trees have been planted by WMA personnel over the last several years. The dividends of these processes are beginning to show up in the vegetation sampling. Woody species were observed in 11 of 46 samples on the Kootenai River floodplain.

The two primary noxious weed species within Boundary Creek WMA are Canada thistle and field sowthistle (Sonchus arvensis). Although reed canarygrass (Phalaris arundinacea) is not considered a noxious weed by Idaho or Boundary County, it is considered a noxious weed a neighboring state (Washington) because of it invasive nature in disturbed areas. The overall cover for Canada thistle (Cirsium arvense) is estimated at $4.15 \%$ coverage and for field sowthistle is estimated at $1.14 \%$. Boundary 
Creek WMA personnel are very aggressive in applying control measures against Canada thistle in the meadow areas. Within this habitat type the cover of Canada thistle was reduced from $14.5 \%$ in 2004 (Antonelli 2005), to 4.5\% in 2007. Reed canarygrass within the marsh communities increased its area of coverage by a factor of ten within three years. During a three year period, reed canarygrass came to dominate 5 of 17 marsh communities, demonstrating its invasive nature.

Aside from the noted increase of reed canary grass within the marsh community, the results from 12 emergent vegetation (marsh) community samples suggests that the marsh vegetation has encroached into the open water and meadow areas. The area of coverage for cattails also increased in the marsh community samples.

Woody species have also increased on the Kootenai River floodplain in the past three years. Within the needle-leaved forest communities, both Pseudotsuga menziesii (Douglas-fir) and Holodiscus discolor (oceanspray) increased their coverages. Cover for Douglas-fir increased from $20.9 \%$ in 2004 , to $25.2 \%$ in 2007. Cover for oceanspray increased from $11.7 \%$ in 2004, to $21.5 \%$ in 2007. Sedge (Carex) species have increased on the Kootenai River floodplain from 2004 to 2007. The cover of sedge species is still less than $0.2 \%$.

\section{Pend Oreille Combined Lands WMA}

During the data collection period in 2007 (May 29 - August 29), 65 samples were completed on the Pend Oreille WMA with 15,507 points surveyed and 26,412 hits (plant species intercepts with the transect line) were observed and recorded (1.70 average hits per point sampled). In all, 357 different species were encountered (Appendix G). To measure the change in vegetative coverage, comparisons were made on a sample by sample basis to those surveyed in 2004 (Antonelli 2005). A total of 46 sample areas were found to be surveyed in both 2004, and 2007.

The estimated noxious weed coverage from this survey $(4.66 \%)$ is higher than the overall noxious coverage $(1.97 \%)$ reported from the 2004 survey. This is due, in part, to the addition of oxeye daisy (Leucanthemum vulgare) to the State of Idaho noxious weed list since the 2004 survey. Oxeye daisy had an estimated $0.84 \%$ coverage on the 2007 survey. In addition, new mitigation properties were added to the Pend Oreille WMA. For instance, the 316-acre Gold Creek property was added to the WMA in 2005, and this property was traditionally grazed and cattle were only recently excluded in 2007. Consequently, Gold Creek had a noxious weed coverage estimated at $7.27 \%$. The primary noxious weeds showing increases were common tansy (Tanacetum vulgare), common St. Johnswort (Hypericum perforatum) and spotted knapweed (Centaurea stoebe). Estimated noxious weed coverage increased on four properties (Rapid Lightning Creek, Denton Slough, Westmond Lake and Cocolalla Lake), decreased on three properties (Derr Creek, Trout Creek and Albeni Cove) and remained unchanged on two properties (Lower Pack River and Carter's Island). Carter's Island still shows almost no noxious weeds with an estimated coverage of $0.08 \%$. 
Similar to the Boundary Creek WMA, reed canarygrass increased in vegetative cover in all areas except in the submergent vegetation. In the submergent vegetation community, reed canarygrass decreased from $45.8 \%$ to $4.2 \%$ in vegetative cover.

Generally, throughout the WMA the dominant species composition of the broad-leaf forests, marsh communities, and pasture lands remained relatively stable. In the broadleaf forests, rose spirea (Spiraea douglasii), black cottonwood (Populus balsamifera ssp. trichocarpa) and bluejoint grass (Calamagrostis canadensis) increased in cover while paper birch (Betula papyrifera) and Kentucky bluegrass (Poa pratensis) had noted decreases in vegetative cover. In the marsh communities, American skunkcabbage (Lysichiton americanus), threepetal bedstraw (Galium trifidum), and broadleaf cattail (Typha latifolia) increased in cover while meadow foxtail (Alopecurus pratensis) decreased. It should be noted, however, that meadow foxtail is a spring grass and its decline may have been due to seasonal senescence with the later survey date.

In contrast to the above community types, the dominate species composition of the meadow, scrub-shrub and submergent vegetation communities were a bit volatile. In the meadow community, five of the six top species had greater than three percent change in absolute percent cover over the three year period. In the scrub-shrub community, 16 of 19 species with greater than five percent cover in at least one of the two survey periods had a greater than three percent change in absolute cover. Moreover, there was a definite shift in the dominate species composition of the submergent vegetation as there were changes in all the dominate species. For instance, Northwest Territory sedge (Carex utriculata), Canada waterweed (Elodea canadensis), water knotweed (Polygonum amphibium) and sago pondweed (Stuckenia pectinatus) all saw increases in vegetative cover. Overall, the total cover for emergent species decreased from $75.4 \%$ to $18.8 \%$ while the total cover for submergent species increased from $1.3 \%$ to $42.9 \%$.

\section{Future Mitigation Projects}

The IDFG is currently working with a landowner to purchase 24 acres adjacent to the Smith Creek WMA in Boundary County. This acquisition is expected to be completed by August 2008. Landowners neighboring the Sullivan property have also expressed interest in a purchased conservation easement. The Larsen property is the final remaining parcel on the Smith Creek fluvial fan that is not protected. This parcel also adjoins the 640-acre Smith Creek WMA. The IDFG is also working with a landowner adjacent to Albeni Cove Habitat Segment in Bonner County. This habitat segment has had an active eagle nest for several years, and the landowner is willing to sell the property directly adjacent to the nesting birds. Some of the last remaining large cedar trees are on this property and provide a buffer to the nesting eagles.

Both the Clark Fork River Delta and the Pack River Delta are listed as the two top mitigation priorities under the Albeni Falls Wildlife Protection, Mitigation, and Enhancement Plan (Martin et al. 1988). Ducks Unlimited partnered with the IDFG, Avista Corporation, other local landowners and non-government organizations to come up with a plan to restore and protect wetlands, and were recently awarded a North 
American Wetlands Conservation Act (NAWCA) grant. The project involves the purchase of conservations easements and the restoration of wetland habitat in the Pack River Delta. Ducks Unlimited and the IDFG are leading restoration efforts in the delta. Erosion of the Pack River Delta by streambank erosion, overland flow erosion, and wave erosion has caused deterioration of the delta. The proposed enhancement project would increase the height and stability of a portion of the summertime submerged islands to improve their functionality, and availability to birds, year-round. Expense funds from the Pend Oreille WMA contract will be used to purchase a Geotube, a critical component to the project. The Geotube works to dissipate wave energy, thereby reducing the wave erosion that occurs because of the high lake levels. The Geotube is a new technology that allows the construction of breakwater deflectors in areas difficult to access and have been successfully used as levees in marine environments. It is hoped that this pilot study will provide valuable information for possible future restoration efforts in the Clark Fork Delta.

The Hoodoo Creek and Hoodoo Lake area, including Beaver Lake and Lamberton Lake, are sixth on the priority list in the Albeni Falls loss assessment (Martin et al. 1988), and are within the Pend Oreille basin. The mitigation goals outlined in the loss assessment calculated that up to $3,880 \mathrm{HU}$ could be directed to this area. While past acquisition attempts by both the IDFG and the KT have failed in the past, opportunity may exist, however, for future restoration and habitat improvement projects in the now degraded Hoodoo Creek and Hoodoo Lake area. Not only would this type of restoration project benefit wildlife, but it would also provide for some fish benefit. Thus, the IDFG are investing possible habitat conservation easement and improvement projects in the Hoodoo Creek drainage area.

\section{Literature Cited}

Albeni Falls Interagency Work Group (AFIWG). 2007. Albeni Falls Wildlife Mitigation Project 2006 Annual Report, Project No. 1992-061-00. 36 pp + appendices.

Antonelli, D. S. 2005. 2004 Vegetation Monitoring and Evaluation Study, Boundary Creek and Pend Oreille Wildlife Management Areas, Albeni Falls Wildlife Mitigation Project. 57 pp. Idaho Department of Fish and Game.

Martin, R. C., H. J. Hansen, and G. A. Meuleman. 1988. Albeni Falls Wildlife Protection, Mitigation, and Enhancement Plan. Idaho Department of Fish and Game. 123 pp. 